\title{
New Steroidal Erythrityl Triesters from the Heat Processed Roots of Panax ginseng
}

\author{
Ill-Min Chung, ${ }^{1}$ Mohd Ali, ${ }^{2}$ Ye-Seul Yang, ${ }^{1}$ Jae-Yeon Yoon, ${ }^{1}$ \\ Youn-Pyo Hong, ${ }^{3}$ and Ateeque Ahmad ${ }^{1}$ \\ ${ }^{1}$ Department of Applied Life Science, Konkuk University, Seoul 143-701, Republic of Korea \\ ${ }^{2}$ Faculty of Pharmacy, Hamdard University, New Delhi 110062, India \\ ${ }^{3}$ Herbal Crop Utilization Research Team, NIHHIS, RDA, Eumseong 369-873, Republic of Korea \\ Correspondence should be addressed to Ateeque Ahmad; ateeque97@gmail.com
}

Received 7 May 2013; Revised 20 August 2013; Accepted 27 August 2013

Academic Editor: Lian-Wen Qi

Copyright (C) 2013 Ill-Min Chung et al. This is an open access article distributed under the Creative Commons Attribution License, which permits unrestricted use, distribution, and reproduction in any medium, provided the original work is properly cited.

Two new compounds stigmasta- $3 \alpha$-ol- $3 \alpha-\left(2^{\prime} R, 3^{\prime} S\right)$-butane- $1^{\prime}, 2^{\prime}, 3^{\prime}, 4^{\prime}$-tetraolyl-2', $3^{\prime}$-dioctadec- $9^{\prime \prime} / 9^{\prime \prime \prime}$-enoyl- $4^{\prime}$-octadec- $9^{\prime \prime \prime \prime}, 12^{\prime \prime \prime \prime}$ dienoate (1) and stigmasta-5-en-3 $\beta$-ol- $3 \beta-\left(2^{\prime} R, 3^{\prime} S\right)$-butane- $1^{\prime}, 2^{\prime}, 3^{\prime}, 4^{\prime}$-tetraolyl-2', $3^{\prime}$-dioctadec- $9^{\prime \prime} / 9^{\prime \prime \prime}$-enoyl- $4^{\prime}$-octadec- $9^{\prime \prime \prime \prime}, 12^{\prime \prime \prime \prime}$ dienoate (2) along with $\beta$-sitosterol- $\beta$-D-glucoside were isolated and identified from the heat processed roots of Panax ginseng. The structures of the new compounds were elucidated by 1D and 2D NMR (COSY, HSQC, and HMBC) spectroscopic techniques aided by FAB-MS, ESI FT/MS, and IR spectra.

\section{Introduction}

Ginseng (Panax ginseng C. A. Meyer, Araliaceae) is one of the most important oriental medicinal plants in Japan, Korea and China [1]. Of the two kinds of ginseng, white ginseng is air dried, and red ginseng is produced by steaming raw ginseng at $98-100^{\circ} \mathrm{C}$ for $2-3 \mathrm{~h}$. It has been reported that red ginseng is more effective in pharmacological activities than white ginseng [2-5]. The differences in biological activities and chemical constituents of red and white ginsengs have been reported. Anticancer properties and other pharmacological activities of Panax ginseng [6-8] have been studied and ginsenosides are recognized as active anticancer compounds [6]. Compared with Asian white ginseng, red ginseng has stronger anticancer activities [9, 10]. Recently, there was a report using a steaming process to treat American ginseng root [5]. In the study, however, the treatment temperature was $100^{\circ} \mathrm{C}$ and, thus, chemical constituents did not change significantly.

Anticarcinogenic and antidiabetic effects of $P$. ginseng have been reported $[9,11]$. Several other compounds and biological activities have been reported from the ginseng roots of $P$. ginseng [12-14]. The most well-known chemical constituent of ginseng is ginsenosides, which are dammarane glycosides. Dammarane glycosides were reported from many parts of ginseng and heat processed $P$. ginseng roots [15, 16]. The chemical and morphological variations of Panax notoginseng and their relationship were recently described [17].

In continuation of our previous work $[18,19]$ on $P$. ginseng roots, two more new compounds were isolated as natural products. This paper deals with the isolation and structure elucidation of two new compounds, stigmasta- $3 \alpha$-ol- $3 \alpha$ $\left(2^{\prime} R, 3^{\prime} S\right)$-butane-1 $1^{\prime}, 2^{\prime}, 3^{\prime}, 4^{\prime}$-tetraolyl-2 $2^{\prime}, 3^{\prime}$-dioctadec- $9^{\prime \prime} / 9^{\prime \prime \prime}$ enoyl- $4^{\prime}$-octadec- $9^{\prime \prime \prime \prime}, 12^{\prime \prime \prime \prime}$-dienoate (1) and stigmasta-5en- $3 \beta$-ol- $3 \beta$ - $\left(2^{\prime} R, 3^{\prime} S\right)$-butane- $1^{\prime}, 2^{\prime}, 3^{\prime}, 4^{\prime}$ - tetraolyl- $2^{\prime}, 3^{\prime}$ dioctadec- $9^{\prime \prime} / 9^{\prime \prime \prime}$-enoyl- $4^{\prime}$-octadec- $9^{\prime \prime \prime \prime}, 12^{\prime \prime \prime \prime}$-dienoate (2), on the basis of ${ }^{1} \mathrm{H}$ and ${ }^{13} \mathrm{C} \mathrm{NMR}$, spectroscopic studies, including 2D-NMR (COSY, HMBC, and HSQC), FAB-MS, ESI FT/MS, IR spectroscopy, and chemical reactions from the heat processed roots of $P$. ginseng. This is the first report of the isolated compounds ( $\mathbf{1}$ and 2 ) from the heat processed roots of $P$. ginseng. Due to the significance of ginseng roots of $P$. ginseng of this plant as a medicinal, the work in this area 
has already been done. The aim of the present investigation is to report some of the new findings in the form of natural products from heat processed roots of $P$. ginseng (Korean red ginseng).

\section{Materials and Methods}

Optical rotation was measured with an instrument on an AA10 model polarimeter (Instruments Ltd,. Seoul, Republic of Korea). IR spectra were recorded on an Infinity Gold FT-IR (Thermo Mattson, Waltham, MA, USA) spectrophotometer, which was available at Korea Institute of Science and Technology, Seoul, Republic of Korea. Both ${ }^{1} \mathrm{H}$ and ${ }^{13} \mathrm{C}-\mathrm{NMR}$ spectra were obtained on a Bruker Avance 600 high-resolution spectrometer operating at 600 and $150 \mathrm{MHz}$, respectively. This NMR machine was available at Seoul National University (SNU), Seoul, Republic of Korea, and all NMR spectra were recorded at SNU (Instrument, Bruker, Germany). NMR spectra were obtained in deuterated chloroform using tetramethylsilane (TMS) as an internal standard, with chemical shifts expressed in ppm $(\delta)$ and coupling constants $(J)$ in Hz. FAB/MS data were recorded on a JMS-700 (Jeol, Mitaka, Japan) spectrometer instrument which was available at SNU, Seoul, Republic of Korea. All chemicals used were of analytical grade. Hexane, ethyl acetate, chloroform, methanol, ethanol, water, sulphuric acid and vanillin were purchased from Daejung Chemicals and Metals Co. Ltd., Republic of Korea. Precoated TLC plates (layer thickness $0.25 \mathrm{~mm}$ ), silica gel for column chromatography (70-230 mesh American Society Testing Materials), and LiChroprep RP-18 (40$63 \mu \mathrm{m}$ ) were from Merck (Darmstadt, Germany). Authentic standards of chemicals were purchased from Sigma-Aldrich, USA. Previously isolated authentic standards of $\beta$-sitosterol$\beta$-D-glucoside were available.

2.1. Plant Material. Fresh ginseng (P. ginseng) was cultivated of ground dried roots ginseng (6 years old) in Ganghwado, Republic of Korea. A voucher specimen (No. PG-R-11) has been deposited at the Department of Applied Life Science, Konkuk University. Korean red ginseng was prepared by using nonpeeled fresh ginseng, which was steamed at $98^{\circ} \mathrm{C}$ for $2 \mathrm{~h}$ using an autoclave. The steamed ginseng after drying and powdered $297.8 \mathrm{~g}$ was prepared for extraction.

2.2. Extraction of Korean Red Ginseng Powder. The Korean red ginseng powder $(297.8 \mathrm{~g})$ was immersed in methanol $(3 \times 1$ litre $)$ for three days at room temperature and then the supernatant was concentrated under vacuum to yield $30.1 \mathrm{~g}$ of the extract, which was suspended in water and extracted with hexane, ethyl acetate, and n-butanol successively to produce $5 \mathrm{~g}, 8.9 \mathrm{~g}$, and $14.2 \mathrm{~g}$ extract, respectively.

2.3. Isolation of the Compounds from Ethyl Acetate Extract. The entire ethyl acetate extract was subjected to normal phase column chromatography over silica gel (500 g) to yield 30 fractions (each of $500 \mathrm{~mL}$ ) with the following eluants: fractions 1-2 with hexane, fractions 2-4 with hexane-chloroform $(9: 1)$, fractions 5-6 with hexane-chloroform $(8: 2)$, fractions $7-8$ with hexanechloroform $(7: 3)$, fractions $9-10$ with hexane:chloroform $(6: 4)$, fractions $11-12$ with hexane:chloroform $(1: 1)$, fractions 13-14 with hexane:chloroform (4:6), fractions 15-16 with hexane:chloroform (3:7), fractions 17-18 with hexane:chloroform (2:8), fractions 19-20 with hexane: chloroform (1:9), fractions 12-22 with chloroform, fractions 23-24 with chloroform: Methanol (9.8:0.2), fractions 25-26 with chloroform: Methanol (9.5:0.5), fractions 27-28 with chloroform: Methanol (9:1), and fractions $29-30$ with $\mathrm{CHCl}_{3}: \mathrm{MeOH}(8.5: 1.5)$. All fractions were examined by TLC. Fractions $1-4$ were not further separated due to the low amount of the substance. Fractions 25-26 (0.9 g) were crystallized after the purification by column chromatography, yielding $\beta$-sitosterol- $\beta$-Dglucoside $(20 \mathrm{mg})$ whose identity was confirmed through the comparison of TLC and spectroscopic data with those of an authentic sample. Fractions 23-24 (1.4 g) were rechromatographed over LiChroprep RP-18 (ODS silica gel; $40-63 \mu \mathrm{m}$ : $100 \mathrm{~g}$; each fraction $100 \mathrm{~mL}$ ). The elution was sequentially performed with methanol and water to yield 10 fractions fractions $1-2$ with $\mathrm{H}_{2} \mathrm{O}: \mathrm{MeOH}(1: 1)$, fractions 3-4 with $\mathrm{H}_{2} \mathrm{O}: \mathrm{MeOH}(2: 8)$, fractions 5-6 with $\mathrm{H}_{2} \mathrm{O}: \mathrm{MeOH}$ (1:9), and fractions $7-10$ with $\mathrm{MeOH}$. Fraction 9 (1.1 g) after rechromatography over silica gel with chloroform and methanol in the ratio of $(9.5: 0.5$ and $9: 1)$ to yield two new compounds 1 (29 $\mathrm{mg}$ ) and $\mathbf{2}$ (23 mg).

2.4. Stigmasta- $3 \alpha$-ol- $3 \alpha-\left(2^{\prime} R, 3^{\prime} S\right)$-butane- $1^{\prime}, 2^{\prime}, 3^{\prime}, 4^{\prime}$-tetraolyl$2^{\prime}, 3^{\prime}$-dioctadec- $9^{\prime \prime} / 9^{\prime \prime \prime}$-enoyl-4' - octadec- $9^{\prime \prime \prime \prime}, 12^{\prime \prime \prime \prime}$ - dienoate (1). Yellow viscous liquid; $R_{f} 0.34 \mathrm{CHCl}_{3}: \mathrm{MeOH}$; $9.5: 0.5$; $[\alpha]_{\mathrm{D}}{ }^{22}: 23.7(\mathrm{MeOH}, c \mathrm{0.2})$; IR (KBr): $\nu\left(\mathrm{cm}^{-1}\right): 2924,2854$, $1740,1733,1721,1645,1458,1376,1165,1073,721 ;{ }^{1} \mathrm{H}$ NMR $\left(600 \mathrm{MHz}_{\mathrm{CDCl}}\right): \delta_{\mathrm{ppm}} 5.38\left(1 \mathrm{H}, \mathrm{m}, \mathrm{H}-9^{\prime \prime}\right), 5.36(1 \mathrm{H}, \mathrm{m}$, $\left.\mathrm{H}-10^{\prime \prime}\right), 5.34\left(1 \mathrm{H}, \mathrm{m}, \mathrm{H}-9^{\prime \prime \prime}\right), 5.32\left(1 \mathrm{H}, \mathrm{m}, \mathrm{H}-10^{\prime \prime \prime}\right), 5.31(1 \mathrm{H}, \mathrm{m}$, $\left.\mathrm{H}-9^{\prime \prime \prime \prime}, \mathrm{H}-10^{\prime \prime \prime \prime}\right), 5.30$ (1H, m, H-12 $\left.2^{\prime \prime \prime \prime}\right), 5.28\left(1 \mathrm{H}, \mathrm{m}, \mathrm{H}-13^{\prime \prime \prime \prime}\right)$, $5.07\left(1 \mathrm{H}, \mathrm{m}, \mathrm{H}-2^{\prime}\right), 4.98\left(1 \mathrm{H}, \mathrm{d}, J=4.8 \mathrm{~Hz}, \mathrm{H}_{2}-4^{\prime} \mathrm{a}\right), 4.30(1 \mathrm{H}$, $\left.\mathrm{d}, J=5.4 \mathrm{~Hz}, \mathrm{H}_{2}-4^{\prime} \mathrm{b}\right), 4.13\left(1 \mathrm{H}, \mathrm{m}, \mathrm{H}-3^{\prime}\right), 4.05(1 \mathrm{H}, \mathrm{br} \mathrm{m}$, $\left.W_{1 / 2}=12.5 \mathrm{~Hz}, \mathrm{H}-3 \beta\right), 3.72\left(1 \mathrm{H}, \mathrm{d}, J=5.2 \mathrm{~Hz}, \mathrm{H}_{2}-1^{\prime} \mathrm{a}\right), 3.70$ $\left(1 \mathrm{H}, \mathrm{d}, J=6.6 \mathrm{~Hz}, \mathrm{H}_{2}-1^{\prime} \mathrm{b}\right), 1.15$ (3H, br s, Me-19), $0.93(3 \mathrm{H}, \mathrm{d}$, $J=6.6 \mathrm{~Hz}, \mathrm{Me}-21), 0.89(3 \mathrm{H}, \mathrm{d}, J=6.5 \mathrm{~Hz}, \mathrm{Me}-26), 0.87(3 \mathrm{H}$, $\mathrm{d}, J=6.3 \mathrm{~Hz}, \mathrm{Me}-27), 0.85(3 \mathrm{H}, \mathrm{t}, J=7.8 \mathrm{~Hz}, \mathrm{Me}-29), 0.84$ $\left(3 \mathrm{H}, \mathrm{t}, J=6.6 \mathrm{~Hz}, \mathrm{Me}-18^{\prime \prime}\right), 0.82\left(3 \mathrm{H}, \mathrm{t}, J=6.6 \mathrm{~Hz}, \mathrm{Me}-18^{\prime \prime \prime}\right)$, $0.80\left(3 \mathrm{H}, \mathrm{t}, J=6.3 \mathrm{~Hz}, \mathrm{Me}-18^{\prime \prime \prime \prime}\right), 0.70$ (3H, br s, Me-18); ${ }^{13} \mathrm{C}-\mathrm{NMR}\left(150 \mathrm{MHz} \mathrm{CDCl}_{3}\right.$ ) see Table 1; FAB-MS (positive ion mode) $(m / z, \%): 1312[\mathrm{M}+\mathrm{H}]^{+}(1.1),\left(\mathrm{C}_{87} \mathrm{H}_{155} \mathrm{O}_{7}\right), 415$ (16.2), 398 (21.2), 282 (11.6), 280 (18.1), 263 (54.5); ESIFT/MS: $m / z 1312.1776[\mathrm{M}+\mathrm{H}]^{+}$(calcd. for $\mathrm{C}_{87} \mathrm{H}_{155} \mathrm{O}_{7}, 1312.1779$ ).

2.5. Stigmasta-5-en-3 $\beta$-ol-3 $\beta-\left(2^{\prime} R, 3^{\prime} S\right)$-butane- $1^{\prime}, 2^{\prime}, 3^{\prime}, 4^{\prime}$-tetraolyl-2', $3^{\prime}$-dioctadec- $9^{\prime \prime} / 9^{\prime \prime \prime}$-enoyl-4 $4^{\prime}$-octadec- $9^{\prime \prime \prime \prime}, 12^{\prime \prime \prime \prime}$-dienoate (2). Yellow semisolid; $R_{f} 0.29 \mathrm{CHCl}_{3}: \mathrm{MeOH}$; 9.5 : 0.5; $[\alpha]_{\mathrm{D}}{ }^{22}: 33.1(\mathrm{MeOH}, c 0.2)$; IR $(\mathrm{KBr}) \nu\left(\mathrm{cm}^{-1}\right): 2958,2830$, $1745,1732,1650,1460,1378,1239,1053,754 ;{ }^{1} \mathrm{H}$ NMR $\left(600 \mathrm{MHz} \mathrm{CDCl}_{3}\right): \delta 5.72\left(1 \mathrm{H}, \mathrm{m}, \mathrm{H}-13^{\prime \prime \prime \prime}\right), 5.40(1 \mathrm{H}, \mathrm{m}$, $\left.\mathrm{H}-12^{\prime \prime \prime \prime}\right), 5.38$ (1H, m, H-10 $\left.{ }^{\prime \prime \prime \prime}\right), 5.35$ (1H, m, H-9 $\left.{ }^{\prime \prime \prime \prime \prime}\right), 5.33$ $(1 \mathrm{H}, \mathrm{m}, \mathrm{H}-6), 5.30\left(1 \mathrm{H}, \mathrm{m}, \mathrm{H}-9^{\prime \prime \prime}\right), 5.26\left(1 \mathrm{H}, \mathrm{m}, \mathrm{H}-9^{\prime \prime}\right)$, 
TABLE $1:{ }^{13} \mathrm{C}$ NMR (150 MHz) spectral data of compounds 1 and 2.

\begin{tabular}{|c|c|c|}
\hline Position & $\delta_{\mathrm{C}}(\mathbf{1})$ & $\delta_{\mathrm{C}}(2)$ \\
\hline 1 & 39.0 & 37.2 \\
\hline 2 & 31.4 & 31.5 \\
\hline 3 & 70.8 & 71.7 \\
\hline 4 & 42.3 & 40.4 \\
\hline 5 & 50.9 & 140.7 \\
\hline 6 & 17.4 & 121.6 \\
\hline 7 & 31.9 & 31.8 \\
\hline 8 & 34.0 & 36.1 \\
\hline 9 & 51.1 & 50.1 \\
\hline 10 & 35.9 & 36.4 \\
\hline 11 & 22.5 & 22.6 \\
\hline 12 & 39.7 & 39.7 \\
\hline 13 & 45.7 & 45.8 \\
\hline 14 & 56.4 & 56.7 \\
\hline 15 & 24.8 & 24.2 \\
\hline 16 & 27.1 & 28.2 \\
\hline 17 & 55.8 & 56.0 \\
\hline 18 & 11.9 & 11.9 \\
\hline 19 & 20.8 & 21.0 \\
\hline 20 & 41.4 & 42.2 \\
\hline 21 & 19.7 & 19.7 \\
\hline 22 & 33.5 & 33.9 \\
\hline 23 & 25.5 & 27.1 \\
\hline 24 & 46.7 & 45.3 \\
\hline 25 & 29.3 & 29.1 \\
\hline 26 & 18.6 & 18.9 \\
\hline 27 & 18.6 & 18.7 \\
\hline 28 & 23.0 & 23.0 \\
\hline 29 & 11.8 & 11.8 \\
\hline $1^{\prime}$ & 61.4 & 61.4 \\
\hline $2^{\prime}$ & 72.0 & 71.1 \\
\hline $3^{\prime}$ & 64.9 & 65.0 \\
\hline $4^{\prime}$ & 62.0 & 62.0 \\
\hline $1^{\prime \prime}$ & 173.8 & 173.8 \\
\hline $1^{\prime \prime \prime}$ & 173.6 & 173.2 \\
\hline $1^{\prime \prime \prime \prime}$ & 173.3 & 171.8 \\
\hline $9^{\prime \prime}$ & 131.8 & 130.1 \\
\hline $10^{\prime \prime}$ & 128.0 & 129.9 \\
\hline $9^{\prime \prime \prime}$ & 130.1 & 129.6 \\
\hline $10^{\prime \prime \prime}$ & 127.8 & 129.2 \\
\hline $9^{\prime \prime \prime \prime}$ & 129.7 & 128.0 \\
\hline $10^{\prime \prime \prime \prime}$ & 127.0 & 127.0 \\
\hline $12^{\prime \prime \prime \prime}$ & 125.3 & 138.2 \\
\hline $13^{\prime \prime \prime \prime}$ & 123.6 & 123.6 \\
\hline $18^{\prime \prime}$ & 14.2 & 14.0 \\
\hline $18^{\prime \prime \prime}$ & 14.0 & 14.0 \\
\hline
\end{tabular}

TABLE 1: Continued.

\begin{tabular}{lcc}
\hline Position & $\delta_{\mathrm{C}}(\mathbf{1})$ & $\delta_{\mathrm{C}}(\mathbf{2})$ \\
\hline $18^{\prime \prime \prime \prime}$ & 14.0 & 13.6 \\
& $34.2,34.1,33.8,33.7$, & $35.6,34.2,34.1,34.0$, \\
$\mathrm{CH}_{2}$ (ester units) & $29.6-29.0,27.9,25.9$, & $31.4,29.6-29.2,28.8$, \\
& $22.6,21.1,21.0,20.4$. & $26.0-24.3,22.5$ \\
\hline
\end{tabular}

$5.14\left(1 \mathrm{H}, \mathrm{m}, \mathrm{H}-10^{\prime \prime}\right), 5.08\left(1 \mathrm{H}, \mathrm{m}, \mathrm{H}-10^{\prime \prime \prime}\right), 5.02(1 \mathrm{H}, \mathrm{dd}, J=$ 8.4, $\left.9.0 \mathrm{~Hz}, \mathrm{H}-2^{\prime}\right), 4.30\left(2 \mathrm{H}, \mathrm{m}, \mathrm{H}_{2}-1^{\prime}\right), 4.96\left(1 \mathrm{H}, \mathrm{m}, \mathrm{H}-3^{\prime}\right)$, $4.06\left(1 \mathrm{H}, \mathrm{d}, J=6.0 \mathrm{~Hz}, \mathrm{H}_{2}-4^{\prime} \mathrm{a}\right), 3.72(1 \mathrm{H}, \mathrm{d}, J=5.4 \mathrm{~Hz}$, $\left.\mathrm{H}_{2}-4^{\prime} \mathrm{b}\right), 3.51\left(1 \mathrm{H}, \mathrm{br} \mathrm{m}, W_{1 / 2}=15.6 \mathrm{~Hz}, \mathrm{H}-3 \alpha\right), 1.01(3 \mathrm{H}, \mathrm{br}$ s, Me-19), $0.92(3 \mathrm{H}, \mathrm{d}, J=6.0 \mathrm{~Hz}, \mathrm{Me}-21), 0.90(3 \mathrm{H}, \mathrm{d}$, $J=6.3 \mathrm{~Hz}, \mathrm{Me}-26), 0.88(3 \mathrm{H}, \mathrm{d}, J=6.1 \mathrm{~Hz}, \mathrm{Me}-27), 0.86$ $\left(3 \mathrm{H}, \mathrm{t}, J=6.5 \mathrm{~Hz}, \mathrm{Me}-18^{\prime \prime}\right), 0.84(3 \mathrm{H}, \mathrm{t}, J=6.2 \mathrm{~Hz}, \mathrm{Me}-$ $\left.18^{\prime \prime \prime}\right), 0.82\left(3 \mathrm{H}, \mathrm{t}, J=6.0 \mathrm{~Hz}, \mathrm{Me}-18^{\prime \prime \prime \prime}\right), 0.80(3 \mathrm{H}, \mathrm{d}, J=$ $6.3 \mathrm{~Hz}, \mathrm{Me}-29), 0.67$ (3H, br s, Me-18); ${ }^{13} \mathrm{C}$ NMR $(150 \mathrm{MHz}$ $\mathrm{CDCl}_{3}$ ) see Table 1; FAB-MS (positive ion mode) $(\mathrm{m} / \mathrm{z}, \%)$ : $1310[\mathrm{M}+\mathrm{H}]^{+}(1.1),\left(\mathrm{C}_{87} \mathrm{H}_{153} \mathrm{O}_{7}\right),(2.7), 413$ (100), 398 (99.8), 395 (98.5), 381 (66.1), 282 (83.0), 280 (21.7), 271 (69.3), 255 (90.2), 213 (92.1); ESIFT/MS: $m / z 1310.1619[\mathrm{M}+\mathrm{H}]^{+}$(calcd. for $\left.\mathrm{C}_{87} \mathrm{H}_{153} \mathrm{O}_{7}, 1310.1622\right)$.

2.6. Alkaline Hydrolysis. A solution of compounds $\mathbf{1}$ and $2(10 \mathrm{mg}$ each) in $5 \%$ dry $\mathrm{KOH} \mathrm{MeOH}(2 \mathrm{~mL})$ was heated under stirring separately at temperature $\left(40-50^{\circ} \mathrm{C}\right)$ for $4 \mathrm{~h}$. The reaction mixture was acidified to $\mathrm{pH} 7.0$ and partitioned between $\mathrm{MeOH}$ and $\mathrm{n}$-hexane. The $\mathrm{n}$-hexane layer containing the fatty acids was confirmed on the basis of TLC. Each solution after separation of the fatty acids was evaporated to dryness and the residue was dissolved in chloroform to isolate steroids ( $\beta$-sitosterol was compared by TLC). Each solid residue was identified as erythritol by HPLC, $R_{t} 13 \mathrm{~min}$ [23].

\section{Results and Discussion}

Compound 1 showed IR absorption bands for ester functions (1740, 1733, $\left.1721 \mathrm{~cm}^{-1}\right)$, unsaturation $\left(1645 \mathrm{~cm}^{-1}\right)$, and long aliphatic chain $\left(721 \mathrm{~cm}^{-1}\right)$. On the basis of FAB mass and ${ }^{13} \mathrm{C}$ NMR spectra, the molecular ion peak of $\mathbf{1}$ was determined at $m / z 1311[\mathrm{M}+\mathrm{H}]^{+}$consistent with the molecular formula of a steroidal erythrityl triester $\mathrm{C}_{87} \mathrm{H}_{155} \mathrm{O}_{7}$. The ion peaks arising at $m / z 415[\mathrm{M} \text { - erythrityl unit }]^{+}$and 398 [415 $\mathrm{OH}]^{+}$suggested stigmastane unit in the molecule. The ion fragments generated at $m / z 282\left[\mathrm{CH}_{3}\left(\mathrm{C}_{16} \mathrm{H}_{30}\right) \mathrm{COOH}\right]^{+}, 280$ $\left[\mathrm{CH}_{3}\left(\mathrm{C}_{16} \mathrm{H}_{28}\right) \mathrm{COOH}\right]^{+}$, and $263[280-\mathrm{OH}]^{+}$indicated that oleic and linoleic acids were esterified with the erythritol unit.

The ${ }^{1} \mathrm{H}-\mathrm{NMR}$ spectrum of $\mathbf{1}$ showed multiple signals from $\delta 5.38$ to 5.28 assigned to eight vinylic protons, oxygenated methine protons of the steroid unit at $\delta 4.05$ with half width of $12.5 \mathrm{~Hz}$ ascribed to $\mathrm{H}-3 \beta$, four one-proton doublets at $\delta$ $4.33(J=4.8 \mathrm{~Hz}), 4.30(J=5.4 \mathrm{~Hz}), \delta 3.72(J=5.2 \mathrm{~Hz})$, and $3.70(J=6.6 \mathrm{~Hz})$, attributed to oxygenated methylene $\mathrm{H}_{2}-1^{\prime}$ and $\mathrm{H}_{2}-4^{\prime}$ protons, and two one-proton multiplets at $\delta$ 5.07 and 4.98 accounted to oxygenated methine $\mathrm{H}-2^{\prime}$ and $\mathrm{H}-$ $3^{\prime}$ protons, respectively. Nine three-proton signals as broad signals at $\delta 1.15$ and 0.70 , as doublets at $\delta 0.93(J=6.6 \mathrm{~Hz})$, 
$0.89(J=6.5 \mathrm{~Hz})$, and $\delta 0.87(J=6.3 \mathrm{~Hz})$, and as triplets between $\delta 0.85$ and, 0.75 were associated with the tertiary C19 , and C-18, secondary C-21, C-26 and C-27, and primary C$29, \mathrm{C}-18^{\prime \prime}, \mathrm{C}-18^{\prime \prime \prime}$, and C- $18^{\prime \prime \prime \prime}$ methyl protons, respectively, all attached to saturated carbons.

The ${ }^{13} \mathrm{C}-\mathrm{NMR}$ spectrum of $\mathbf{1}$ exhibited signals for ester carbons at $\delta 173.8\left(\mathrm{C}-1^{\prime \prime}\right), 173.6\left(\mathrm{C}-1^{\prime \prime \prime}\right)$, and $173.3\left(\mathrm{C}-1^{\prime \prime \prime \prime}\right)$, vinylic carbons between $\delta 131.8$ and 123.6, steroidal oxygenated methine carbon at $\delta 68.2(\mathrm{C}-3)$, erythritol carbons at $\delta 61.4\left(\mathrm{C}-1^{\prime}\right), 72.0\left(\mathrm{C}-2^{\prime}\right), 64.9\left(\mathrm{C}-3^{\prime}\right)$, and $62.0\left(\mathrm{C}-4^{\prime}\right)$, and methyl carbons from $\delta 20.8$ to 11.8. The stereochemistry of the steroids at C-3 oxygenated methine proton was established by coupling interaction of the ${ }^{1} \mathrm{H}$ NMR spectral data and by comparison of the ${ }^{1} \mathrm{H}$ and ${ }^{13} \mathrm{C}$ NMR values of the steroidal carbon frameworks with the reported steroidal data [20-22]. The poliol was detected as erythritol by comparing retention time by HPLC [23].

The ${ }^{1} \mathrm{H}-{ }^{1} \mathrm{H}$ COSY spectrum of 1 showed correlations of $\mathrm{H}-3$ with $\mathrm{H}_{2}-2$ and $\mathrm{H}_{2}-4 ; \mathrm{H}-2^{\prime}$ with $\mathrm{H}^{\prime} 1^{\prime}$ and $\mathrm{H}-3^{\prime}$; $\mathrm{H}-9^{\prime \prime} / \mathrm{H}-9^{\prime \prime \prime}$ with $\mathrm{H}-10^{\prime \prime} / \mathrm{H}-10^{\prime \prime \prime}$ and $\mathrm{H}_{2}-11^{\prime \prime \prime \prime}$ with $\mathrm{H}-9^{\prime \prime \prime \prime}$, $\mathrm{H}-10^{\prime \prime \prime \prime}, \mathrm{H}-12^{\prime \prime \prime \prime}$, and $\mathrm{H}-13^{\prime \prime \prime \prime}$. The HMBC spectrum of 1 that exhibited interactions of proton carbon relations is shown in Figure 3. The HSQC spectrum of 1 showed correlation of $\mathrm{H}-3$ ( $\delta$ 4.05), $\mathrm{H}_{2}-1^{\prime}(\delta 3.70,3.72), \mathrm{H}-2^{\prime}(\delta 5.07), \mathrm{H}-3^{\prime}(\delta$ $4.13)$, and $\mathrm{H}-4^{\prime}(\delta 4.33,4.30)$ with the respective oxygenated carbons C-3 ( $\delta$ 68.2), C-1 ${ }^{\prime}\left(\delta\right.$ 61.4), C- $2^{\prime}\left(\delta\right.$ 72.0), C-3 ${ }^{\prime}$ $\left(\delta\right.$ 64.9), and $C-4^{\prime}(\delta$ 62.0) and vinyl and methyl protons with their corresponding carbon signals. The absence of a carbon signal between $\delta 110$ and 90 supported the linkage of erythritol moiety to the steroid. Alkaline hydrolysis of 1 yielded 3-epistigmastanol oleic and linoleic acids (TLC comparable) and erythritol (HPLC comparable). On the basis of foregoing description, the structure of 1 was elucidated as stigmasta- $3 \alpha$-ol- $3 \alpha-\left(2^{\prime} R, 3^{\prime} S\right)$-butane- $1^{\prime}, 2^{\prime}, 3^{\prime}, 4^{\prime}$-tetraolyl$2^{\prime}, 3^{\prime}$-dioctadec- $9^{\prime \prime} / 9^{\prime \prime \prime}$-enoyl- $4^{\prime}$-octadec- $9^{\prime \prime \prime \prime}, 12^{\prime \prime \prime \prime}$-dienoate (1, Figure 1). This is a new steroidal erythrityl trimester.

Compound 2 showed distinctive IR absorption bands for ester groups $\left(1745,1732 \mathrm{~cm}^{-1}\right)$, unsaturation $\left(1650 \mathrm{~cm}^{-1}\right)$, and aliphatic chain $\left(754 \mathrm{~cm}^{-1}\right)$. It had a molecular ion peak at $\mathrm{m} / z$ $1309[\mathrm{M}+\mathrm{H}]^{+}$determined on the basis of FAB mass and ${ }^{13} \mathrm{C}$ NMR spectra consistent with the molecular formula steroidal erythritol triester, $\mathrm{C}_{87} \mathrm{H}_{153} \mathrm{O}_{7}$. The ion peaks arising at $\mathrm{m} / \mathrm{z}$ $413[\mathrm{M} \text { - erythtrityl triester }]^{+}, 398[413-\mathrm{Me}]^{+}, 395[413-$ $\mathrm{OH}]^{+}$, and $381[398-\mathrm{Me}]^{+}$suggested that $\beta$-sitosterol was present as an aglyconic unit. It was also supported by the ion

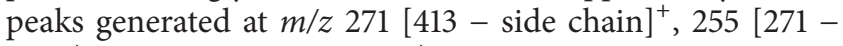
$\mathrm{OH}]^{+}$, and $213[255-\text { ring }]^{+}$. The ion fragments produced at $m / z 282\left[\mathrm{CH}_{3}\left(\mathrm{CH}_{2}\right)_{7} \mathrm{CH}=\mathrm{CH}\left(\mathrm{CH}_{2}\right)_{7} \mathrm{COOH}\right]^{+}$and 280 $\left[\mathrm{CH}_{3}\left(\mathrm{C}_{16} \mathrm{H}_{28}\right) \mathrm{COOH}\right]^{+}$indicated that oleic and linoleic acids were esterified with erythritol unit.

The ${ }^{1} \mathrm{H}-\mathrm{NMR}$ spectrum of $\mathbf{2}$ showed nine one-proton multiplets between $\delta 5.72$ and 5.08 assigned to vinylic protons of the steroid and fatty acid units. A one-proton double doublet at $\delta 5.02(J=8.4,9.0 \mathrm{~Hz})$, a two-proton multiplet at $\delta 4.30$, a one-proton multiplet at $\delta 4.96$, and two oneproton doublets at $\delta 4.06(J=6.0 \mathrm{~Hz})$ and $3.72(J=5.4 \mathrm{~Hz})$ were ascribed to the erythritol protons $\mathrm{H}-2^{\prime}, \mathrm{H}_{2}-1^{\prime}, \mathrm{H}-3^{\prime}$, and $\mathrm{H}_{2}-4^{\prime}$, respectively. A one-proton broad multiplet at $\delta$
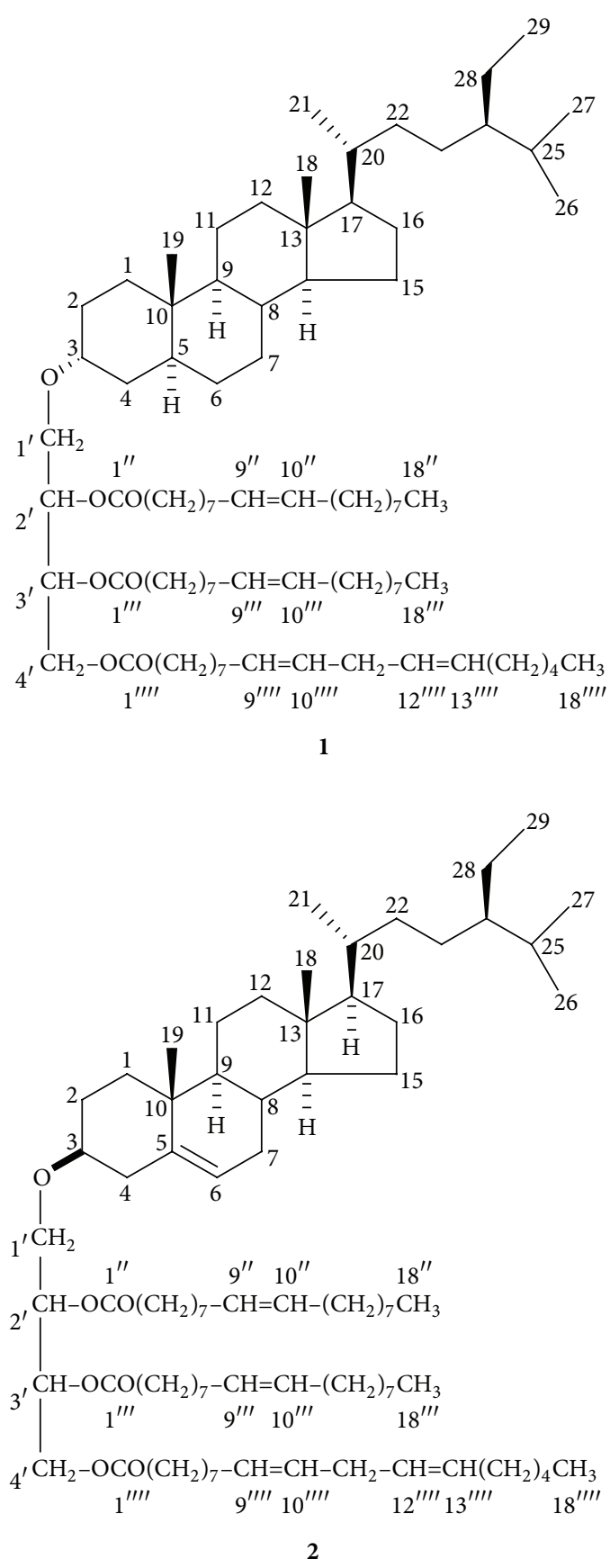

FIgURE 1: Chemical structures of compounds 1 and 2.

3.51 with half width of $15.6 \mathrm{~Hz}$ was due to oxygenated $\mathrm{H}-3 \alpha$ methine proton. Nine three-proton signals as broad singlets at $\delta 1.01$ and 0.67 , as doublets at $\delta 0.92(J=6.0 \mathrm{~Hz}), 0.90$ $(J=6.3 \mathrm{~Hz})$, and $0.88(J=6.1 \mathrm{~Hz})$, and as triplets at $\delta 0.86$ $(J=6.5 \mathrm{~Hz}), 0.84(J=6.2 \mathrm{~Hz}), 0.82(J=6.0 \mathrm{~Hz})$, and 0.80 $(J=6.3 \mathrm{~Hz})$ were associated with the tertiary C-18 and C-19, secondary C-21, C-26, and C-27, and primary C-18", $\mathrm{C}-18^{\prime \prime \prime}$, C-18 ${ }^{\prime \prime \prime \prime}$, and C-29 methyl protons, respectively, all attached to saturated carbons. The ${ }^{13} \mathrm{C}$-NMR spectrum of 2 exhibited important signals for ester carbons at $\delta 173.8\left(\mathrm{C}-1^{\prime \prime}\right), 173.2$ $\left(\mathrm{C}-1^{\prime \prime \prime}\right)$, and $171.8\left(\mathrm{C}-1^{\prime \prime \prime \prime}\right)$, vinylic carbons between $\delta 140.7$ and 123.6, oxygenated steroidal methine carbon at $\delta 71.7$ 


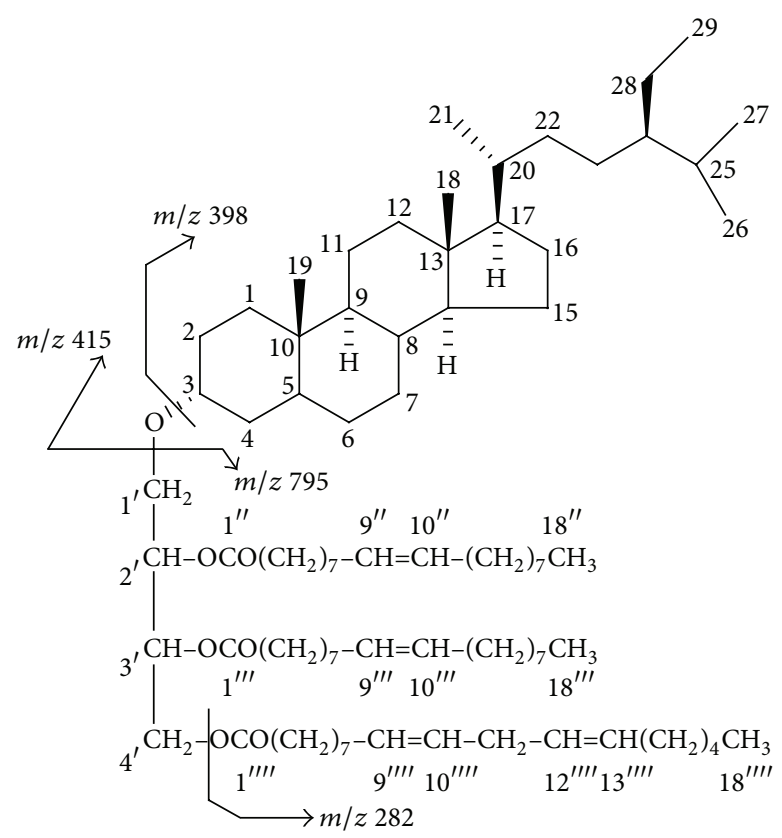

1

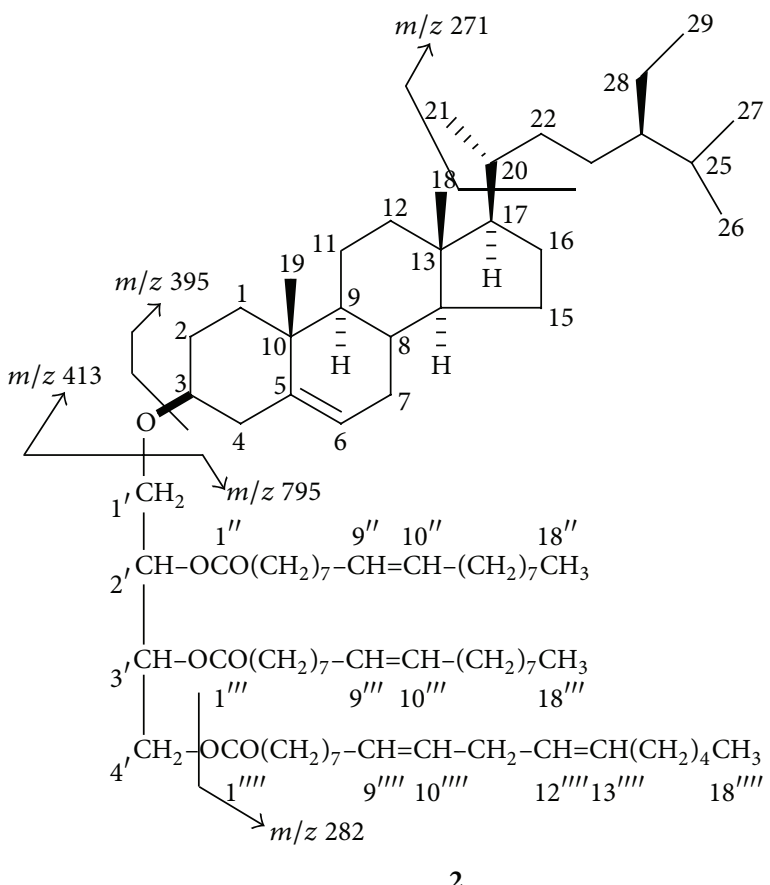

Figure 2: Mass fragmentation pattern of compounds 1 and 2.

(C-3), and erythritol carbons at $\delta 61.4\left(\mathrm{C}-1^{\prime}\right), 68.1\left(\mathrm{C}-2^{\prime}\right)$, $65.0\left(\mathrm{C}-3^{\prime}\right)$, and $62.0\left(\mathrm{C}-4^{\prime}\right)$, methyl carbons from $\delta 21.0$ to 11.8. The absence of an anomeric carbon signals from $\delta 110$ to 90 supported erythritol unit attached to the steroid. The stereochemistry of the steroids at C-3 oxygenated methine proton was established by coupling interaction of the ${ }^{1} \mathrm{H}$ NMR spectral data and by comparison of the ${ }^{1} \mathrm{H}$ and ${ }^{13} \mathrm{C}$ NMR values of the steroidal carbon frameworks with the reported steroidal data [20-22]. The poliol was detected as erythritol by comparing retention time by HPLC [23].

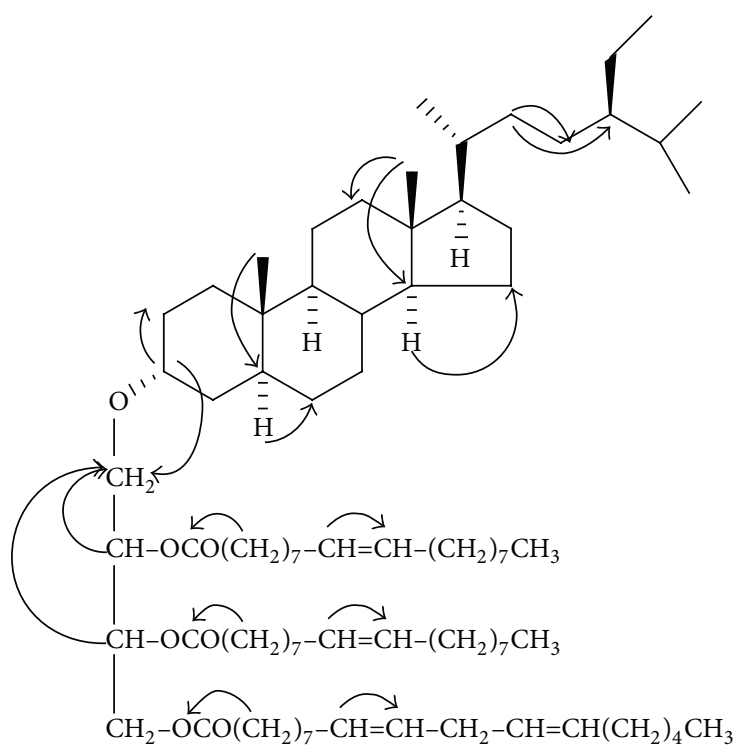

1

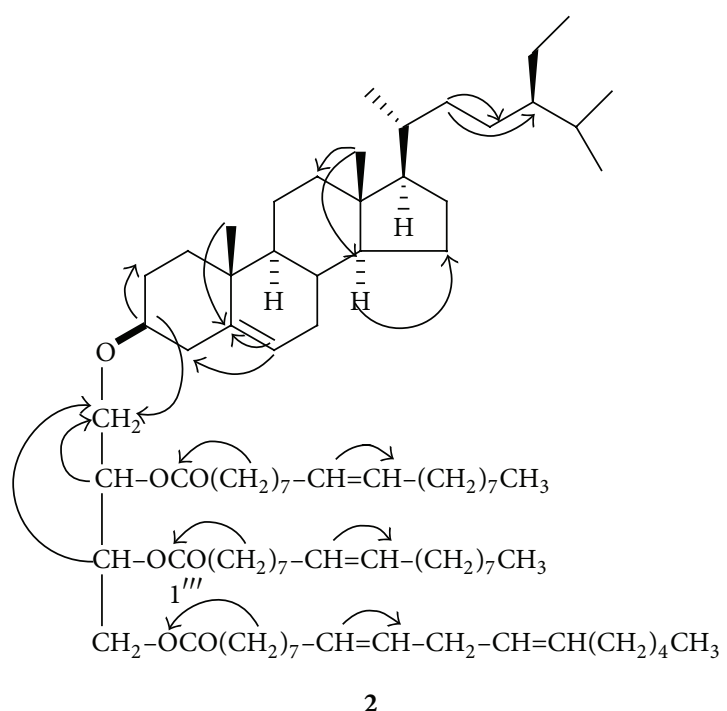

Figure 3: Key HMBC correlations of new compounds 1 and 2.

The ${ }^{1} \mathrm{H}^{-}{ }^{1} \mathrm{H}$ COSY spectrum of 2 showed correlations of $\mathrm{H}-3$ with $\mathrm{H}_{2}-2$ and $\mathrm{H}_{2}-4 ; \mathrm{H}-6$ with $\mathrm{H}_{2}-4, \mathrm{H}_{2}-7$, and $\mathrm{H}-8$; $\mathrm{H}-2^{\prime}$ with $\mathrm{H}_{2}-1^{\prime}, \mathrm{H}-3^{\prime}$, and $\mathrm{H}_{2}-4^{\prime}$; and $\mathrm{H}_{2}-11^{\prime \prime \prime \prime}$ with $\mathrm{H}-9^{\prime \prime \prime \prime}, \mathrm{H}-10^{\prime \prime \prime \prime}, \mathrm{H}-12^{\prime \prime \prime}$, and $\mathrm{H}-13^{\prime \prime \prime \prime}$. The key HMBC correlations of 2 that exhibited interactions of proton carbon relations are shown in Figure 3. The HSQC spectrum of 2 showed correlations of $\mathrm{H}-3$ at $\delta 3.51$ with $\mathrm{C}-3$ at $\delta$ 71.22; $\mathrm{H}_{2}-1^{\prime}$ at $\delta 5.02$ with $\mathrm{C}-2^{\prime}$ at $\delta 68.19 ; \mathrm{H}_{2}-1^{\prime}$ at $\delta 4.30$ with $\mathrm{C}-1^{\prime}$ at $\delta$ 61.36; $\mathrm{H}-3^{\prime}$ at $\delta 4.13$ with $\mathrm{C}-3^{\prime}$ at $\delta$ 65.01, and $\mathrm{H}_{2}-4^{\prime}$ at $\delta 3.72$ and 3.51 with $\mathrm{C}-4^{\prime}$ at $\delta$ 62.07. Alkaline hydrolysis of $\mathbf{2}$ yielded $\beta$-sitosterol, oleic and linoleic acids, TLC comparable. These lines of evidence led to the formulation of the structure of 2 as stigmasta-5-en- $3 \beta$-ol-3 $\beta$ $\left(2^{\prime} R, 3^{\prime} S\right)$-butane-1', $2^{\prime}, 3^{\prime}, 4^{\prime}$-tetraolyl-2 $2^{\prime}, 3^{\prime}$-dioctadec- $9^{\prime \prime} / 9^{\prime \prime \prime}$ enoyl- $4^{\prime}$-octadec- $9^{\prime \prime \prime \prime}, 12^{\prime \prime \prime \prime}$-dienoate $(2$, Figure 2$)$. This is a new steroidal erythrityl triestrer. 


\section{Conclusion}

Two new compounds stigmasta- $3 \alpha$-ol- $3 \alpha-\left(2^{\prime} R, 3^{\prime} S\right)$-butane-1' $1^{\prime}, 2^{\prime}, 3^{\prime}, 4^{\prime}$-tetraolyl-2', $3^{\prime}$-dioctadec- $9^{\prime \prime} / 9^{\prime \prime \prime}$-enoyl- $4^{\prime}$-octadec- $9^{\prime \prime \prime \prime}, 12^{\prime \prime \prime \prime}$-dienoate $(1)$ and stigmasta-5-en-3 $\beta$-ol-3 $\beta$ $\left(2^{\prime} R, 3^{\prime} S\right)$-butane-1 $1^{\prime}, 2^{\prime}, 3^{\prime}, 4^{\prime}$-tetraolyl-2 $2^{\prime}, 3^{\prime}$-dioctadec- $9^{\prime \prime} / 9^{\prime \prime \prime}$ enoyl- $4^{\prime}$-octadec- $9^{\prime \prime \prime \prime}, 12^{\prime \prime \prime \prime}$-dienoate $(2)$ were isolated from the methanolic extraction of heat processed roots of $P$. ginseng. A lot of work already studied $P$. ginseng compounds and biological activity. Further studies on the $P$. ginseng compounds and bioactivity are also needed.

\section{Acknowledgment}

This work was carried out with the support of Cooperative Research Program for Agriculture Science \& Technology Development (PJ0083022011), Rural Development Administration, Republic of Korea.

\section{References}

[1] M. K. Ang-Lee, J. Moss, and C. S. Yuan, "Herbal medicines and perioperative care," The Journal of the American Medical Association, vol. 286, no. 2, pp. 208-216, 2001.

[2] T. Takaku, K. Kameda, Y. Matsuura, K. Sekiya, and H. Okuda, "Studies on insulin-like substances in Korean red ginseng," Planta Medica, vol. 56, no. 1, pp. 27-30, 1990.

[3] J. H. Do, H. O. Lee, S. K. Lee, K. B. Noh, S. D. Lee, and K. S. Lee, "Comparisons of acidic polysaccharide contents in various ginseng species and parts," Korean Journal of Ginseng Science, vol. 17, no. 2, pp. 145-147, 1993.

[4] W. Y. Kim, J. M. Kim, S. B. Han et al., "Steaming of ginseng at high temperature enhances biological activity," Journal of Natural Products, vol. 63, no. 12, pp. 1702-1704, 2000.

[5] C. Z. Wang, H. H. Aung, M. Ni et al., "Red American ginseng: ginsenoside constituents and antiproliferative activities of heatprocessed Panax quinquefolius roots," Planta Medica, vol. 73, no. 7, pp. 669-674, 2007.

[6] S. Helms, "Cancer prevention and therapeutics: Panax ginseng," Alternative Medicine Review, vol. 9, no. 3, pp. 259-274, 2004.

[7] J. T. Xie, S. Mchendale, and C. S. Yuan, "Ginseng and diabetes," The Americam Journal of Chinese Medicine, vol. 33, no. 3, pp. 397-404, 2005.

[8] C. J. Liou, W. C. Huang, and J. Tseng, "Long-term oral administration of ginseng extract modulates humoral immune response and spleen cell functions," The American Journal of Chinese Medicine, vol. 33, no. 4, pp. 651-661, 2005.

[9] T. K. Yun, Y. S. Lee, Y. H. Lee, S. I. Kim, and H. Y. Yun, "Anticarcinogenic effect of Panax ginseng C.A. Meyer and identification of active compounds," Journal of Korean Medical Science, vol. 16, supplement, pp. S6-S18, 2001.

[10] H. H. Yoo, T. Yokosawa, A. Satoh, K. S. Kang, and H. Y. Kim, "Effects of ginseng on the proliferation of human lung fibroblasts," The American Journal of Chinese Medicine, vol. 34, no. 1, pp. 137-146, 2006.

[11] A. S. Attele, Y. P. Zhou, J. T. Xie et al., "Antidiabetic effects of Panax ginseng berry extract and the identification of an effective component," Diabetes, vol. 51, no. 6, pp. 1851-1858, 2002.

[12] N. Fukuyama, M. Shibuya, and Y. Orihara, "Antimicrobial polyacetylenes from Panax ginseng hairy root culture," Chemical and Pharmaceutical Bulletin, vol. 60, no. 3, pp. 377-380, 2012.
[13] M. C. Rho, H. S. Lee, S. W. Lee et al., "Polyacetylenic compounds, ACAT inhibitors from the roots of Panax ginseng," Journal of Agricultural and Food Chemistry, vol. 53, no. 4, pp. 919-922, 2005.

[14] I. H. Park, N. Y. Kim, S. B. Han et al., "Three new dammarane glycosides from heat processed ginseng," Archives of Pharmacal Research, vol. 25, no. 4, pp. 428-432, 2002.

[15] N. Baek, D. S. Kim, Y. H. Lee, J. D. Park, C. B. Lee, and S. I. Kim, "Ginsenoside Rh4, a genuine dammarane glycoside from Korean red ginseng," Planta Medica, vol. 62, no. 1, pp. 86-87, 1996.

[16] J. H. Ryu, J. H. Park, J. H. Eun, J. H. Jung, and D. H. Sohn, "A dammarane glycoside from Korean red ginseng," Phytochemistry, vol. 44, no. 5, pp. 931-933, 1997.

[17] D. Wang, H. I. Koh, Y. Hong et al., "Chemical and morphological variations of Panax notoginseng and their relationship," Phytochemistry, vol. 93, no. 3, pp. 88-95, 2013.

[18] I. M. Chung, M. Y. Kim, N. Praveen, Y. P. Hong, and A. Ahmad, "Fatty acid constituent from the heat processed roots of Panax ginseng," Asian Journal of Chemistry, vol. 25, no. 2, pp. 10861088, 2013.

[19] I. M. Chung, M. Ali, Y. P. Hong, and A. Ahmad, "New compound from the heat processed roots of Panax ginseng," Asian Journal of Chemistry, vol. 25, no. 8, pp. 4667-4669, 2013.

[20] I. M. Chung, M. Ali, T. D. Khanh, M. G. Choung, H. J. Park, and A. Ahmad, "New stigmastane steroids constituents from rice hulls of Oryza sativa and inhibitory activity on radish seed," Bulletin of the Korean Chemical Society, vol. 27, no. 1, pp. 93-98, 2006.

[21] I. M. Chung, M. Ali, A. Ahmad, J. D. Lim, C. Y. Yu, and J. S. Kim, "Chemical constituents of rice (Oryza sativa) hulls and their herbicidal activity against duckweed (Lemna paucicostata Hegelm 381)," Phytochemical Analysis, vol. 17, no. 1, pp. 36-45, 2006.

[22] I. M. Chung, M. Ali, A. Ahmad et al., "Steroidal constituents of rice (Oryza sativa) hulls with algicidal and herbicidal activity against blue-green algae and duckweed," Phytochemical Analysis, vol. 18, no. 2, pp. 133-145, 2007.

[23] T. Shindou, Y. Sasaki, H. Miki, T. Eguchi, K. Hagiwara, and T. Ichikawa, "Identification of erythritol by HPLC and GC-MS and quantitative measurement in pulps of various fruits," Journal of Agricultural and Food Chemistry, vol. 37, no. 6, pp. 1474-1476, 1989. 

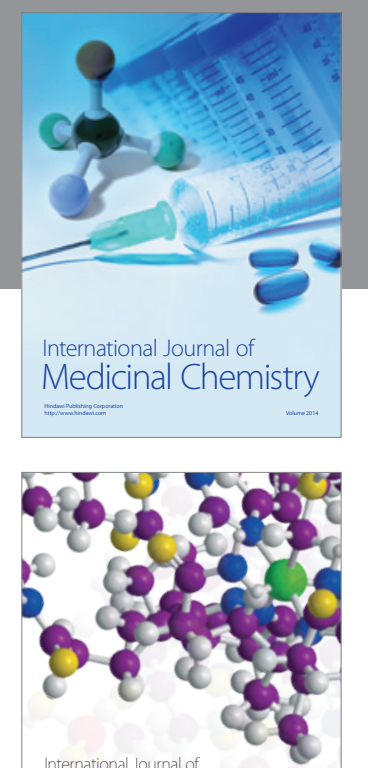

\section{Carbohydrate} Chemistry

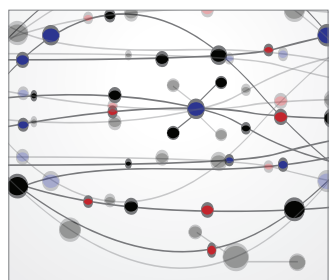

The Scientific World Journal
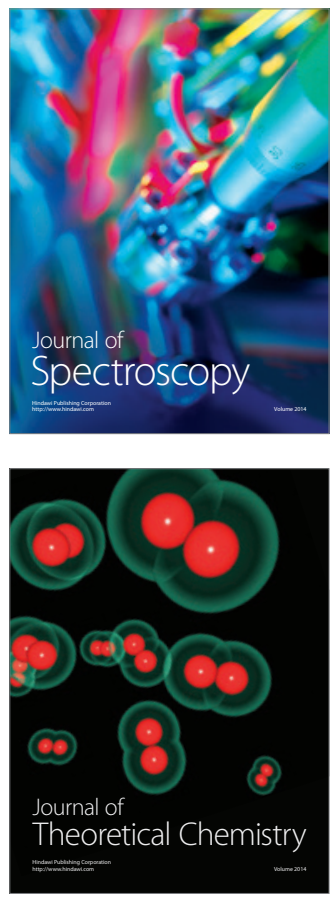
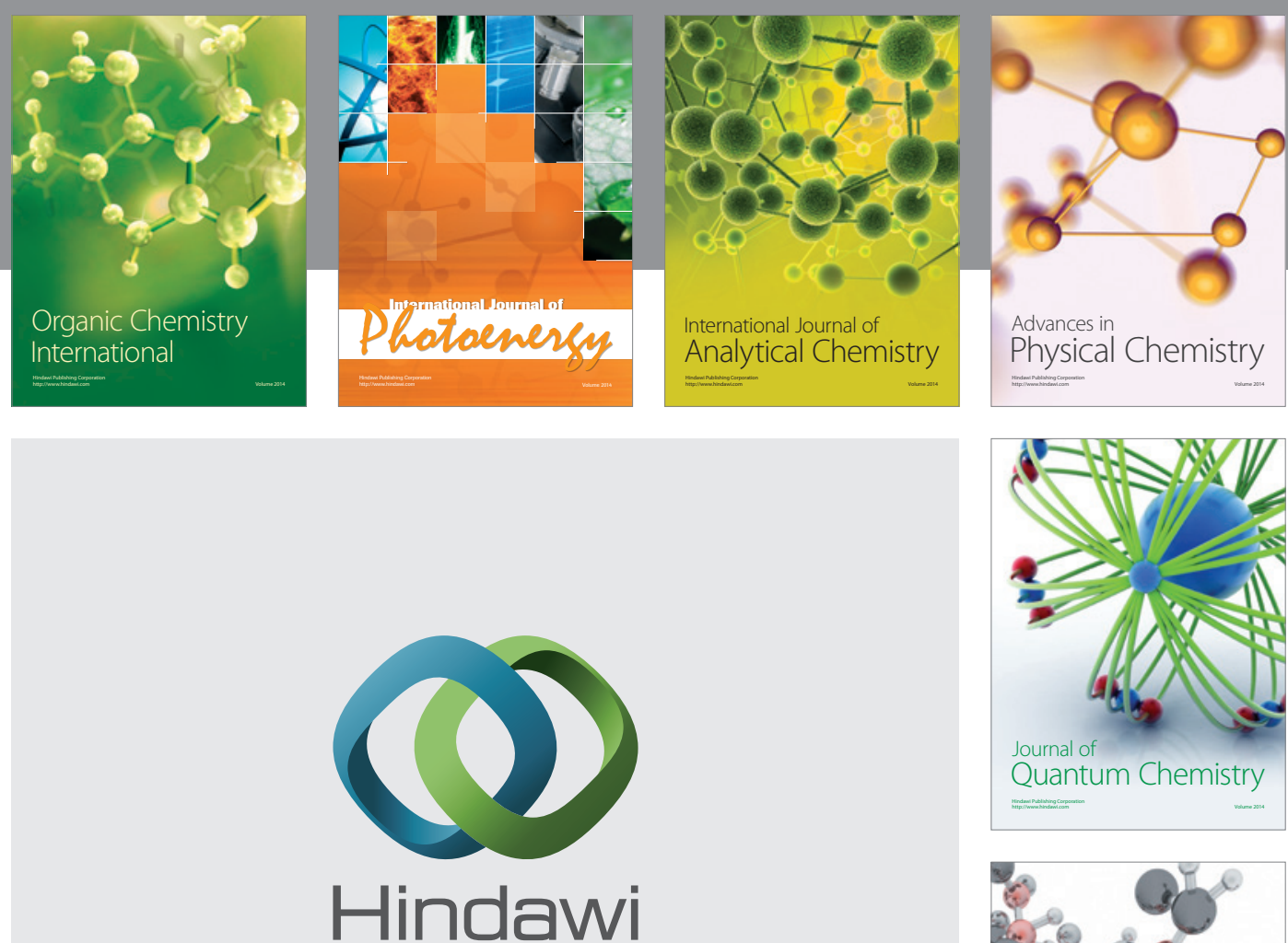

Submit your manuscripts at

http://www.hindawi.com

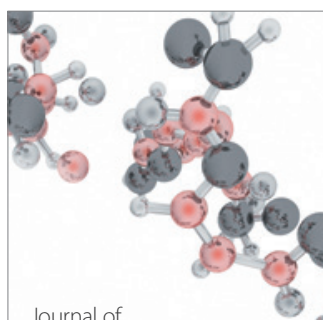

Analytical Methods

in Chemistry

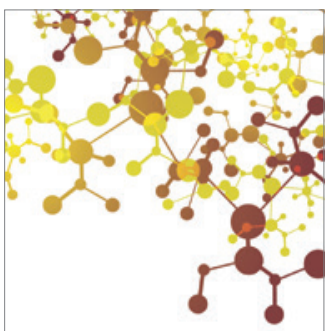

Journal of

Applied Chemistry

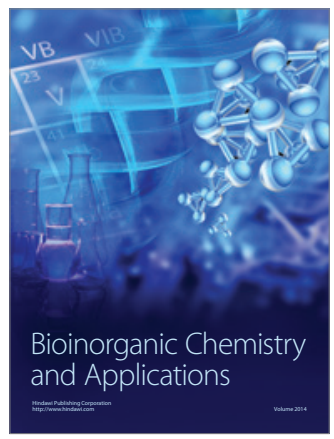

Inorganic Chemistry
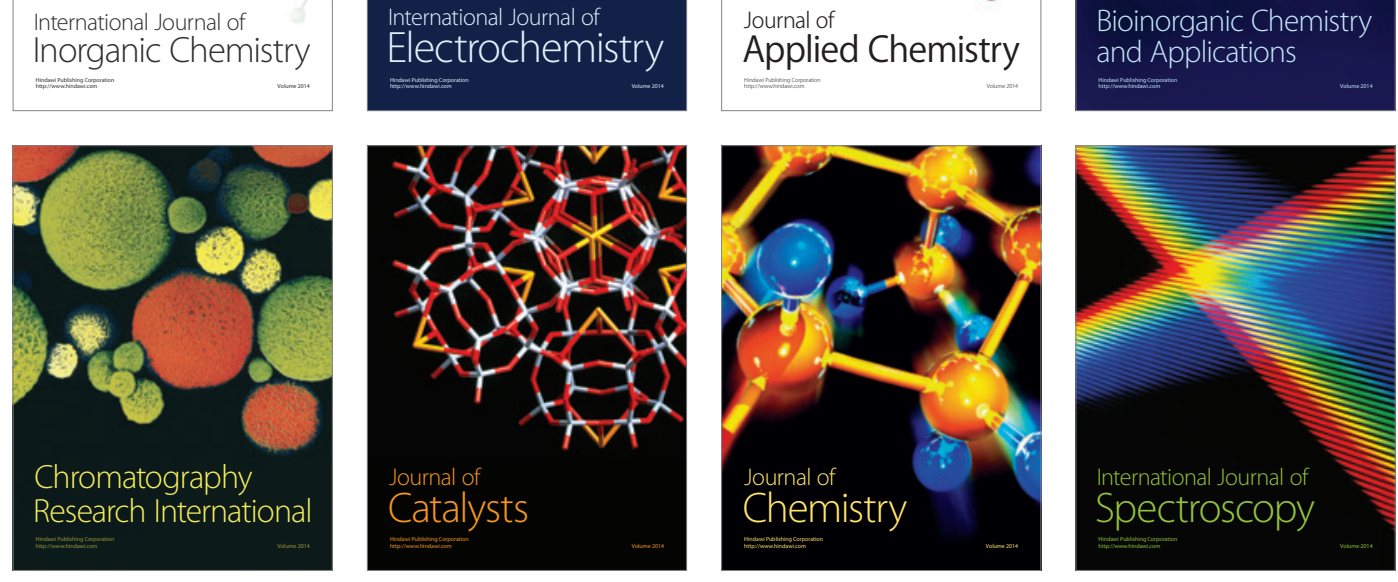